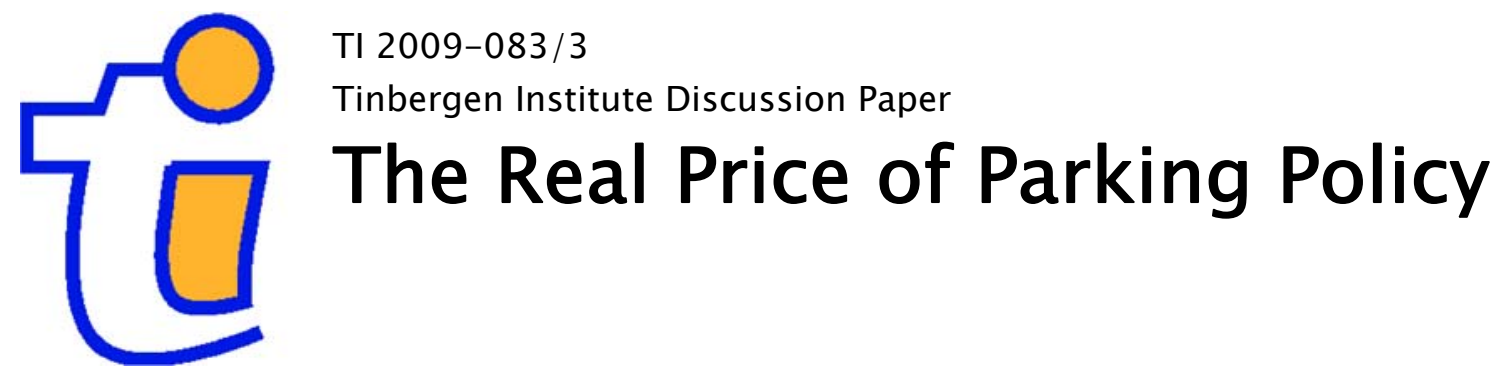

Jos van Ommeren*

Derk Wentink

Jasper Dekkers

Faculty of Economics and Business Administration, VU University Amsterdam.

* Tinbergen Institute. 


\section{Tinbergen Institute}

The Tinbergen Institute is the institute for economic research of the Erasmus Universiteit Rotterdam, Universiteit van Amsterdam, and Vrije Universiteit Amsterdam.

Tinbergen Institute Amsterdam

Roetersstraat 31

1018 WB Amsterdam

The Netherlands

Tel.: +31(0)205513500

Fax: $+31(0) 205513555$

Tinbergen Institute Rotterdam

Burg. Oudlaan 50

3062 PA Rotterdam

The Netherlands

Tel.: + $31(0) 104088900$

Fax: $+31(0) 104089031$

Most TI discussion papers can be downloaded at http://www.tinbergen.nl. 


\title{
The real price of parking policy
}

\author{
Jos van Ommeren \\ Derk Wentink \\ Jasper Dekkers
}

$23 / 09 / 2009$

The authors are associated with the VU University, FEWEB, De Boelelaan, 1081 HV Amsterdam, the Netherlands; Email: jommeren@feweb.vu.nl. They would like to thank the Dutch association of real estate agents (NVM) for providing housing data.

Abstract. This paper is the first to empirically examine the residents' willingness to pay for onstreet parking permits as well as the cost of cruising using an identification methodology based on house prices for Amsterdam. The average cost of cruising is $€ 1.30$ per day. The average residents' willingness to pay for a parking permit is $€ 8$ per day. Further, we show that the introduction of paid parking in a neighborhood decreases house prices in this neighbourhood. 


\section{Introduction}

In the literature on the economics of on-street parking, parking policy has received substantial attention (Vickrey, 1969; Arnott et al., 1991; Verhoef et al., 1995; Borger and Wuyts, 2007; Proost and van Dender, 2008). A general conclusion is that, given heterogeneity of demand for on-street parking, it is welfare improving to impose parking tariffs. Furthermore, these tariffs must be the same for different users of parking spaces. In reality however, parking policies discriminate between residents and non-residents. In large cities, residents frequently have access to parking permits which allow them to park at a fraction of the parking tariffs faced by other users. Economic theory suggests therefore that this policy will generally induce large inefficiencies. There are exceptions, of course. The main exception is when the residents' willingness to pay for parking exceeds the on-street parking tariff. Then, this type of policy may be justified. So, the first motivation of the current paper is to estimate the residents' willingness to pay for parking permits and to compare this measure to the on-street parking tariff.

In the literature the importance of cruising for on-street parking has come to the fore (e.g., Glazer and Niskanen, 1992; Calthrop, 2002; Anderson and De Palma, 2004; Arnott and Inci, 2006; Shoup, 2005, 2006). It is generally believed that in downtown areas in large cities, due to underpricing of parking space, cruising for parking implies substantial welfare losses. As emphasised by Arnott and Inci (2006), traffic experts do not know what proportion of cars on the downside city streets are cruising for parking, although studies such as Shoup (2005) suggest that the average share of traffic cruising for parking is 30 percent and the average cruising time just under 8 minutes. Cruising involves costs not only because of additional cruising time, but also because of additional walking time to the point of destination (Arnott and Rowse, 1999). In addition, cruising creates uncertainty about the total travel time, which is known to create 
additional costs (e.g., Small et al., 2005). Although cruising is key to this literature, there are no empirical estimates of the costs associated with cruising. Therefore, the second motivation of this paper is to estimate the residents' costs for cruising for parking. ${ }^{1}$

In order to identify the residents' willingness to pay for parking permits as well as the residents' cost of cruising, we use a combination of methodological steps. First, we focus on capitalisation of residential parking characteristics (in particular, private parking spaces) into house prices. Although the use of house prices as an identification strategy is obvious for economists, the empirical parking literature ignores this strategy completely. ${ }^{2}$ Second, we employ area fixed effects estimation techniques. By including fixed effects, we control for a myriad of unobserved spatial factors that may determine house prices, including local congestion and the number of on-street parking lots. Although the application of area fixed effects is standard in the hedonic house price literature, we employ areas that are much smaller than usual, which makes the identification strategy more convincing. In our sample, the average distance between houses within the same area is only 28 metres. Third, we make use of the institutional environment of Amsterdam, where the large majority of residents (91 percent in our sample) do not have private parking and may have to cruise for parking places near their residence. We make use of the observation that owners of residences with private parking places do not have to cruise, thus employing information about private parking allows us to estimate the residents' cost of cruising. Fourth, in Amsterdam, about most residents live in paid-parking districts (70 percent in our sample) and about one out of four residents in these districts has to wait for parking

\footnotetext{
${ }^{1}$ In the current paper, we focus on the private costs of cruising. However, cruising may also induce additional congestion, noise, stench, dust particles and $\mathrm{CO}_{2}$-emission and therefore will increase societal costs of travel. These external costs are not included in the estimates.

${ }^{2}$ In a range of empirical hedonic housing price models, the presence of private parking is included, but exact interpretation of the estimated effects in terms of cruising costs etc is not possible (e.g. Stevenson, 2004; Goodman and Tibodeau, 2003).
} 
permits. The average waiting time is more than three years. We are able to derive the residents' willingness to pay for parking permits using information about the private parking spaces in areas with waiting lists for parking permits, which are capitalised into house prices.

The outline of the paper is as follows. In Section 2, we shortly discuss the relationship of our empirical paper with the theoretical literature. In Section 3, we describe the institutional parking environment for Amsterdam. Then we introduce the methodology to identify the residents' cost of cruising for parking, as well as the willingness to pay for on-street parking permits in Section 4. Furthermore, we discuss the econometric methodology to identify the effect of changes in parking policy on changes in house prices. In Section 5, we discuss the data and in Section 6 the empirical results of the estimated hedonic price models. Section 7 concludes our paper.

\section{Literature}

The setting of our empirical study that focuses on residents' parking in Amsterdam is closely related to essentially all theoretical studies concerning on-street parking (e.g. Vickrey, 1969; Verhoef et al., 1995). These studies universally recommend the use of parking tariffs. We aim to examine the effect of parking tariffs on house prices, which helps us to examine the welfare implications for residents.

We will limit our discussion of cruising to studies which focus exclusively on cruising (Arnott and Inci, 2006; Anderson and de Palma, 2004). Arnott and Inci (2006) assume an urban area where on-street parking may, or may not, be fully saturated. Parking duration per trip is fixed. They then focus on optimal parking policy, when the government may not use a congestion toll, but may levy a parking fee and may determine the number of on-street parking 
lots (these assumptions are in line with the situation for Amsterdam). Cruising for parking is shown to be pure deadweight loss. The optimal policy implies that the parking fee should be raised to the point where cruising for parking is just eliminated and the number of on-street parking spaces must be chosen such that the parking fee equals the congestion externality. Although one may argue that this result only holds under a number of potentially restrictive assumptions (e.g., it is not clear whether the saturation assumption is too restrictive), the key message is important for our study, because it implies that the deadweight loss of cruising for residents is equal to the residents' private cost of cruising identified in the current paper.

Anderson and de Palma (2004) also analysed the economics of cruising but explicitly model the expected number of parking spots searched before finding a vacant one. Hence, the costs of search are a function of the (endogenously determined) parking vacancy rate. They show that the market equilibrium with unpriced parking lots is socially inefficient, because the vacancy rate is too low. This result is consistent with transport engineers who advice a vacancy rate of about 10 to 20 per cent in order to avoid cruising (Shoup, 2005). In this model, welfare can be improved by local governments by setting an optimal parking tariff. This result is relevant, because in Amsterdam, parking tariffs are substantial in most locations. However, in particular in the evening, demand for parking is dominated by residents with parking permits who return from work and as a consequence, parking vacancy rates in many streets are close to zero after 7 p.m. until early morning

In the literature on the economics of parking, the study by Glazer and Niskanen (1992) suggests that the use of parking permits, in addition to a parking fees per unit of time, may be welfare improving. Using a partial model, Glazer and Niskanen (1992) demonstrate that when congestion is untolled, a higher parking tariff per unit of time may not substitute for a congestion 
toll, because it induces additional demand for parking and can therefore increase traffic congestion. In contrast, a positive lump-sum parking tariff may substitute for a congestion toll and therefore increase welfare, as the demand for parking as well as the demand for travel will fall. This result may be relevant in the context of residential on-street parking pricing, as it gives some justification for the use of residential parking permits that will indeed reduce the demand for parking as well as the demand for car travel. ${ }^{3}$ We emphasise that in most cities, including Amsterdam, parking permits are essentially provided for free. Hence, the study by Glazer and Niskanen (1992) suggests that the price of parking permits should be increased.

\section{Parking policy in Amsterdam}

Parking environments policies strongly differ between cities (and countries), so we will shortly describe the relevant characteristics for parking in Amsterdam. ${ }^{4}$ Private residential parking (as well as parking through parking lot operators) is extremely limited: only 9 percent of residences have a private parking spot (also the capacity of private parking lot operators is a small fraction of the number of residences), whereas 79 percent have at least one car, ${ }^{5}$ so the large majority of residents rely on on-street car parking. About 70 percent of residences are located in areas with paid-parking. In these areas, residents can apply for parking permits that are essentially (subsidised) lump-sum parking fees. Residents' parking permit fees are maximally $€ 0.80$ per day. On-street parking tariffs are substantial (on average, $€ 2.20$ per hour), but there are no

\footnotetext{
${ }^{3}$ Note that given the assumption that the residents' parking time is given, which may be a reasonable assumption, then a parking permit and a parking fee per unit of time are equivalent, and the results by Glazer and Niskanen (1992) do not apply.

${ }^{4}$ We use data on owned residences for Amsterdam. So, our discussion refers to owners of residences in Amsterdam, except when stated otherwise.

${ }^{5}$ This statistic has been calculated using a national housing demand survey that includes information about car ownership (Dutch Housing Survey, 2002).
} 
congestion tolls. ${ }^{6}$ In contrast to many other cities in the world (e.g. London, Paris), there are essentially no permit-only parking areas, so all on-street parking space is available to all users (non-residents, residents with parking permits, residents without parking permits). As a result, residents with permits still have to cruise for parking lots (except those with private parking). ${ }^{7}$

One important, but possibly unusual, characteristic of the parking policy in Amsterdam is that in areas with paid-parking, on-street parking permits are only offered to households occupying residences without private parking. Furthermore, any household may maximally receive one permit (with the exception of a few small areas where households do not receive any parking permit and one small area where households may receive two parking permits). The parking permit is valid only in the area directly surrounding the residence, so the permit is used for residence parking and seldom for other purposes (e.g. commuter parking). ${ }^{8}$

Finally, it is important to understand the conditions for obtaining a parking permit. First, obtaining a permit requires one to have a registered address in the neighbourhood for which the permit is issued. Second, applying for a permit requires one to own a car; this condition will prove very important in the invitations of the results later on. Third, about 25 percent of the residences in paid parking areas are located in areas where there is a waiting list for obtaining a parking permit with an average duration of more than 3 years. The number of households on a

\footnotetext{
${ }^{6}$ On-street parking charges are high compared to the rest of the world. In fact, only in London are parking charges higher.

${ }^{7}$ We have employed the Dutch Housing Survey (WBO, 2002) to derive that 62 percent of households own one car, 16 percent own two or more cars, whereas 21 percent do not own a car. For the whole population (including renters), ownership of cars in Amsterdam is comparable to other European cities such as London, Berlin, and Paris (about 300 cars per thousand inhabitants).

${ }^{8}$ The Amsterdam parking policy seems to imply that from an efficiency perspective the share of residents with one car will be too high. Given the structure of parking tariffs, one may expect that the share of households with two cars in Amsterdam is less than one may expect based on characteristics of households. This has been supported by empirical evidence.
} 
waiting-list is estimated to be about 30 percent of the number of households with a parking permit obtained after waiting. ${ }^{9}$

\section{Identification methodology}

In the current paper, we aim to identify $(i)$ the residents' costs of cruising for parking and (ii) the residents' willingness to pay for on-street parking permits using a hedonic house price estimation procedure. We make standard assumptions about the housing market (Rosen, 1974). Hence, we assume a perfectly competitive housing market with many buyers and sellers, where a continuum of house and environmental attributes are available. In order to estimate the cost of cruising and the willingness to pay for on-street parking permits, we will focus on the pricing of one specific housing attribute: private off-street parking space.

To simplify the exposition, we will assume that we have data about houses that are in exactly the same location and are identical except for the presence of off-street parking space. ${ }^{10}$ Owners of houses that are at the same location face exactly the same external conditions relevant for car use (the number of on-street parking spaces near the residence, the level of congestion, on-street parking tariffs), so differences in house prices only reflect differences in the presence of (off-street) parking space.

\subsection{The costs of cruising}

The basic idea we aim to exploit to identify the cost of cruising is that residents who own a parking lot (and use it for parking, and not for other purposes) do not have to cruise, whereas residents without private parking (who have a parking permit) may have to cruise for on-street

\footnotetext{
${ }^{9}$ This has been estimated based on the ratio of residence duration and waiting time duration.

${ }^{10}$ E.g., imagine two apartments in the same building, but one of the apartments has a private parking lot.
} 
parking. To identify the cruising costs, one has to take into account: (i) demand for parking lots other than demand for car parking, (ii) the cost and availability of parking permits, (iii) physical differences between offstreet and on-street parking lots, and (iv) differences in preferences for on-street or off-street parking.

First, we have to take into account that residents may have a demand for off-street parking space that is unrelated to car parking. This is particularly so in areas where on-street parking is for free and there is sufficient on-street parking, so demand for parking is never saturated. In these areas, residents' private parking lots are frequently not used for car parking, but for other purposes (e.g. storage, playfield for children), whereas the residents' cars are parked on-street (usually in front of the house). Therefore, we focus only on houses in areas with on-street paid parking. In these areas, private parking lots will seldomly be used for other purposes than car parking, because on-street parking charges are substantial (recall that households of residences with private parking do not have access to parking permits) which makes it extremely unlikely that households will use their parking lot for other activities than for parking.

Second, one has to take into account the fee for the parking permit. It turns out however that for Amsterdam these fees are small, so, for now, let us assume that parking permit fees are absent. ${ }^{11}$ In addition, it must be guaranteed that there is a sufficient number of permits available. In certain areas of Amsterdam, there are waiting lists for parking permits. We will take this into account by controlling for the length of the waiting list (as well as using interaction terms for waiting lists and parking places).

Third, we have to take into account that on-street parking lots differ from offstreet parking lots in terms of size as well as in protection of the car. So we will control for different types type

\footnotetext{
${ }^{11}$ In our application, we will take these fees, which are indeed small, into account.
} 
of off-street parking lot (e.g. type of garage) and focus on off-street private parking lots that are outside (and therefore do not rely on any parking construction). ${ }^{12}$ Fourth, we have to assume that in the absence of cruising, residents are indifferent between off-street outside parking and onstreet parking in front of their residence. ${ }^{13}$ Let us be more precise about this. Given heterogeneity of households, it is plausible that some households will prefer off-street parking (e.g., those with expensive cars), whereas other households will prefer on-street parking (e.g., those who may make many trips per day). Households with a preference for off-street parking will then sort themselves into houses with off-street parking places.

Given these conditions (parking lots are only used for car parking, no parking permit fees, permits are freely available, standardised parking lots) and one additional assumption (indifference between on-street parking in front of their residence and off-street parking), households will be indifferent between on-street and (private) outside off-street parking only when it is guaranteed that the on-street parking lot in front of their residence is vacant. The latter condition will only be satisfied given the absence of cruising. Hence, given the presence of cruising, households will prefer private outside off-street parking, and the monetary value attached to (not) having to cruise will capitalise in the house price.

In terms of econometric specification, this implies that we must focus on outside private parking lots. We are mainly interested in the effect of private outside off-street parking on house prices when the residence is in a paid-parking area, in other words, in the interaction between outside private parking and the presence of paid-parking. Recall that we have assumed that we

\footnotetext{
${ }^{12}$ Note, however, that our results indicate that in areas with paid parking the economic value of a private parking space is the same for outside parking lots as for garages, indicating that when parking spaces are used for car parking, residents are rather indifferent between the type of parking implying that controlling for different types is not essential.

${ }^{13}$ The indifference assumption implies that there is always at least one vacant on-street parking spot at negligible walking distance of the residence.
} 
have data on houses which are at the same location and are identical except for the presence of a parking space. In this case, the effect of the interaction variable of outside off-street parking with paid-parking captures the households' costs of cruising for parking (near the residence). ${ }^{14}$

\subsection{The residents' willingness to pay for on-street parking permits}

In the current paper, we also aim to identify the residents' willingness to pay for on-street parking permits. ${ }^{15}$ In paid-parking areas of Amsterdam, residents without off-street parking lots have the right to buy one on-street parking permit, but in some areas, the number of parking permits supplied by the local government does not meet the demand for permits. The number of parking permits is district-specific and parking districts use a waiting list leading to waiting times which vary by district. ${ }^{16}$ Now suppose we have information about two residences at the same location. The household of one residence has to wait a certain time before obtaining the parking permit, whereas the household of the other residence does not have to wait as it owns a private parking lot. In this situation, the former household (who does not have a parking permit) has to pay the same on-street parking fees as other users or make use of alternatives (such as parking at the edge of the cities where paid parking is absent), or use commercial off-street parking operators. Identification of the residents' willingness to pay for on-street parking permits is now possible

\footnotetext{
${ }^{14}$ Arguably, the assumption that the marginal household is indifferent between parking in front of their residence or off-street is restrictive. Note that the theoretical literature on the decision between on-street and off-street (commercial) parking either assumes that (conditional on cruising) car drivers are indifferent (e.g. Arnott., 2006) or assumes that drivers prefer on-street parking (Calthrop, 2001), suggesting that our estimates of cruising are conservative (too low).

15 In the current paper, we ignore renters, who are subject to the same parking policy as owners. As renters typically have below-average incomes, it is plausible that the willingness to pay for parking by renters is less than that of owners.

${ }^{16}$ Households may only join a parking permit waiting list (that is specific to their residence region) when they have moved to regions in Amsterdam with a waiting list. Under specific circumstances, residents that are on a waiting list and move to another region with a waiting list, may use their elapsed waiting time to get a higher position on the waiting list.
} 
because, in areas with queues, the utility derived of having a parking lot, and not having to wait for a parking permit, is capitalised into house prices. We have calculated the costs for parking only in the evenings and during the weekend in areas with waiting lists. The average daily cost of on-street parking is $€ 20$, so parking on the street can thus becomes an extremely costly matter for residential parking.

\subsection{Unobserved spatial heterogeneity}

In the estimation approaches discussed above, one must pay much more attention than usual to unobserved spatial heterogeneity, because the residents' value derived from private as well as onstreet parking depends much more on local circumstances than most other characteristics that are relevant to households (e.g., the size of the house). For example, it is not uncommon that in one street the number of parking places is saturated, whereas a few blocks further a number of parking places is vacant. In this situation, the estimated effect of private parking on house prices might be inconsistent due to omitted variable bias, when it is not taken into account that houses are located in different streets.

In an ideal setting, as discussed above, one would like to have information about houses that are all in exactly the same geographical location (on top of each other, such as apartments). In this extreme situation, unobserved spatial heterogeneity can be ignored. We will see that our empirical approach comes close to this ideal setting: we use an area fixed-effects estimation approach, where the average distance between houses within the same area is only 28 metres. 


\section{Data, descriptives and econometric methodology}

The main aim of our paper is estimating the residents' willingness to pay for certain parking characteristics. This essentially entails attaching a monetary value to the marginal utility that residents derive from these characteristics. Our empirical approach is estimating a hedonic housing pricing function, in which the specific features of parking are included in the regression as well as a large number of housing, spatial and parking policy characteristics.

Information about house prices is provided by the Dutch association of real estate agents, NVM (see Gautier et al., 2009, for a similar application). In Amsterdam, the NVM is involved in approximately 90 percent of all housing transactions. The original dataset received by NVM contains 29,606 housing transactions that took place between January 2004 and December 2008. In Amsterdam, there are about 90,000 (owned) houses, so our dataset contains approximately one third of all housing stock.

We know the exact location of each house (the street and house number) and a large number of detailed housing attributes (e.g. garden, the number of rooms). Importantly for the current paper, a distinction is made between five types of private parking spaces: an outside parking spot, a carport, a garage (for one car), a combined carport and garage (for two cars), and a large garage (for two cars). ${ }^{17}$

We do not have information about the size of the outside parking spot, so we do not know the number of cars that can be parked on this spot. Fortunately, this lack of information is not problematic, because in the relevant areas we focus on, outside parking spots are seldomly large enough to contain more than one car, except for a small proportion of single-family dwellings. To guarantee that the outside parking spot contains only one car, we exclude single-

\footnotetext{
${ }^{17}$ A carport is usually attached to a house, with a roof, but not fully enclosed by walls. A garage is fully enclosed by walls.
} 
family dwellings. We also exclude observations that are extreme outliers. ${ }^{18}$ The analysis is based on 24,804 observations. The average house price is $€ 251,159$.

In the Netherlands, the most detailed administrative neighbourhood unit is defined by the 6-digit zip code. Six digit zip code areas are small, and in Amsterdam typically include 12 residences (that are on the same side of one street). The average distance between houses within a zip code area is only 28 metres, whereas only 5 percent of the observations are within an area for which the average distance is more than hundred metres. In our sample, we distinguish between 6,241 areas, so the mean number of observations per area is about 4 .

In the analysis, we apply area fixed effects, but arguably even within these small areas, spatial variation in house prices may occur, because of variation in closeness to the city centre and in local environmental characteristics such as noise and other amenities. Hence, we also control for distance to the city centre, the nearest railway station and the nearest highway ramp.

Because it is fundamental to our identification strategy that we control for unobserved spatial heterogeneity, we have re-estimated all models selecting only observations for which the average distance between houses of the same area is less than hundred metres. Given this selection, the average distance between houses of the same area is only 22 metres. As the results with the selected observations are identical to the original sample with all observations, we only report the results based on the original sample.

From several offices of the municipality of Amsterdam, we have obtained information about parking tariffs by neighbourhood, as well as information regarding the (expected) length of waiting-lists for parking permits. Parking tariffs and waiting times vary per year and per area.

\footnotetext{
${ }^{18}$ More specifically, all housing with a price of less than $€ 30,000$ or more than $€ 4,000,000$, with a housing area below 20 square metres or with more than 10 rooms are excluded. Further, a-typical types of accommodations, such as houseboats, are excluded from the sample.
} 
The average parking tariff is $€ 2.30$ per hour. The average waiting time for obtaining a parking permit is 39 months. Waiting times are not administrative data that are obligatory to collect, but are derived by us based on information using a combination of measures (e.g., recent waiting times, number of parking permits issued over a certain period combined with number of households waiting). Waiting time is therefore measured with substantial measurement error, whereas at the same time changes in waiting lists are generally small. To avoid identification based on measurement errors in changes in waiting times, we will not use the exact waiting time but employ only a dummy indicator of the presence of a waiting list. ${ }^{19}$ Later on we will also distinguish between areas with short waiting lists (less than 1 year) and areas with long waiting lists (between 1 and 5 years). ${ }^{20}$ About 37 percent of residences in paid parking areas are located in an area with a waiting list for parking permits.

Table 1 provides basic information about the average house price, the percentage of residences in a waiting-list area and the percentage of residences with private parking. It indicates that all residences in areas with a hourly parking tariff that exceeds $€ 3.50$ and 17 percent of residences in areas with lower tariffs are situated in a waiting list area (areas without paid-parking do not have waiting-lists as no parking permit is required here for on-street parking). The table also shows that 9.7 percent of all residences have a private parking space, and 3.2 percent an outside parking spot.

\footnotetext{
${ }^{19}$ For a small number of observations, the waiting time is less than 4 weeks. We assume that the waiting time for these observations is zero.
} 


\section{Empirical results}

\subsection{Main results}

Table 2 provides the results of the fixed effects hedonic price analysis. In addition to areaspecific parking characteristics specific for the area (low and high parking tariffs, presence of waiting list for parking permit) and the presence of a private parking space, we include a large number of controls specific to the residence. We emphasise that we allow the estimated effects of the parking lots to depend on whether the residence is only in a paid-parking area or whether the residence is also in an area with a waiting-list for permits. The reported standard errors allow for clustering based on area in line with Moulton (1990).

Our first main result is that in areas with paid-parking, an outside parking spot increases the house price by 6.8 percent (see column (1) in Table 2). The second main result is that if the house is also located in a waiting-list-area, then the presence of an outside parking spot increases the house price by an additional 5.7 percent. $^{21}$ The third main result is that the introduction of paid-parking reduces house prices by 3.7 percent, but there is no difference between the effects of low or high parking tariffs. Note that during the period of observation, parking tariffs have never decreased, so the effect of the low parking tariff can be interpreted as the effect of the introduction of paid-parking. The fourth main result is that the introduction of a waiting-list for parking permits seems to reduce house prices (the point estimate is -1.7 percent), but the effect is statistically insignificant. Note that the latter effect is entirely identified using changes over time in the presence of waiting lists, so it is likely that we will need a longer period with more pronounced changes in the waiting lists to identify this effect appropriately.

\footnotetext{
${ }^{21}$ Thus, the total increase in the house price for an outside parking spot in a waiting-list area is 12.5 percent. It is important to realize that these results are average effects, so these percentages may vary through the city.
} 
The first main result allows us to derive the cost of cruising for parking. Recall that the cost of cruising for parking can be derived from the effect of an outside parking spot on the house price in a paid-parking area, which is 6.8 percent of the house price. The average housing price in a paid-parking area is $€ 279,593$, implying that the capitalised cruising cost is $€ 19,012$. Interpretation of this measure is not so straightforward, so we prefer to have a measure for the daily cruising costs. To estimate these costs, one has to assume a discount rate and take into account that the mortgage interest expenses for housing is deductible from labour income in the Netherlands. Assuming a 50 percent marginal income tax rate ${ }^{22}$ and a 5 percent discount rate, the annual cruising cost is $€ 473$, implying a daily cruising cost of $€ 1.30$. This cost entails the time cost of searching for the parking spot, walking time, and the cost of uncertainty involved in searching the spot. As this is the first study to measure this cost, we cannot benchmark this result by comparing it to other studies, but this result seems reasonable to us. For example, let us assume that the resident's value of travel time (including uncertainty) ranges from $€ 10$ to $€ 20$ per hour. Then, the average implied cruising time per day is 4 to 8 minutes, in line with Shoup (2005).

Recall that the results by Arnott and Inci (2006) imply that the deadweight loss of cruising is equal to the residents' private cruising cost. Household income of home owners in the paid-parking area of Amsterdam is about $€ 70,000$ per year, indicating that the deadweight loss for cruising is 0.7 percent of income. Clearly, the loss of cruising is substantial.

To estimate the households' willingness to pay for parking permits, we focus on the second main result which shows that an outside parking-spot increases the house price by an

\footnotetext{
${ }^{22}$ In the Netherlands, for owners of housing, there are two marginal income tax levels. The 52 percent level applies to annual incomes exceeding $€ 54,776$. The 42-percent-level applies to annual incomes ranging from $€ 17,878$ to $€ 54,775$.
} 
additional 5.7 percent for residences in waiting-list areas. In these areas, the average housing price is $€ 321,324$. Hence, the capitalised households' willingness to pay for a private (outside) parking lot to avoid waiting for a parking permit is $€ 20,156$. Again we have to take into account that mortgage interest payments are tax-deductible, so the capitalised willingness to pay (given a 50 percent marginal income tax rate) implies a value of $€ 10,078$. Again, we find it more convenient to have a measure per day. The average waiting time is 1,170 days (39 months), so the households' average willingness to pay to immediately receive a parking permit is $€ 8.55$ per day.

The households' willingness to pay for a parking permit far exceeds the parking permit tariff (which is less than $€ 0.80$ per day), suggesting inefficient use of parking space. Furthermore, the households' willingness to pay is much lower than the daily on-street parking tariff, which is on average $€ 20$ with a minimum of $€ 12$ (these parking tariffs have been calculated given the assumption that during weekdays only evening parking is required, otherwise the weekly cost would be substantially higher). ${ }^{23}$ This makes it plausible that the willingness to pay for the parking permit is not a one-to-one function of the on street parking tariff, but measures the willingness to pay for parking given the alternative choices available to households to avoid on street parking close to the residence (e.g. parking in the periphery of the city, parking with private operator garages, not having a car). ${ }^{24}$

We are in deriving some other welfare implications of the Amsterdam parking policy. In many downtown areas, it is common to observe that the (implicit) price for on-street parking is

\footnotetext{
${ }^{23}$ Note that if the households' willingness to pay exceeds the parking tariff, then the willingness to pay as measured by us would be equal to the parking tariff and waiting for the parking permit would have no behavioural consequences.

${ }^{24}$ In order to register for the waiting list households must have a car. It is plausible however that many households register their car when buying property and then sell the car.
} 
much lower for residents than for non-residents. One plausible explanation is that residents have voting power and therefore impose a parking tariff structure that favours residents. It may be thought that residents will favour higher on-street parking tariffs if sufficient parking permits are issued, as this reduces demand for parking, and therefore decreases residents' cruising costs. This will certainly be true if parking tariffs also decrease congestion and residents ignore the negative impact on visitors. In Amsterdam however, residents receive maximally one parking permit, so residents with a demand for (more than) two cars (e.g., two-earner households) are more likely to prefer lower on-street charges (if they ignore the revenue effect of parking policy).

Total tax revenues from parking policy in Amsterdam mount to $€ 131$ million, about $€$ 570 per residence (in paid parking areas). Let us assume that the revenues of the paid parking policies as measured by us are not capitalised into house prices. This assumption may be appropriate because parking charges for Amsterdam are street-specific whereas revenues are effectively used per parking district, so increases in the local parking tariff of a certain street have negligible influence on any reductions in local taxes in the street (see, Shoup, 2004, who argues for such a local tax system, where revenues from local parking tariffs are recycled to local residents).

Based on our estimates, paid-parking reduces housing prices by approximately 4 percent. Recall that we use area fixed effects, and the level of parking tariffs is the same within each area. Hence, the effect of paid parking is identified using differences over time. It is plausible that changes in local parking tariff can be considered exogenous with anticipated local changes in house prices, so the identified effect can be interpreted as causal. ${ }^{25}$ The average housing price in paid-parking areas is approximately $€ 280,000$, so the reduction is about $€ 11,200$, which is

${ }^{25}$ Changes in parking tariffs are usually announced about two months before the actual change takes place (so in November the is announced, and in January or February the change takes place). 
equivalent to an annual loss of $€ 280$ per household (given a discount rate of 5 percent and a mortgage reduction of 50 percent). Thus, for house owners, the direct loss (ignoring revenues) caused by paid-parking is $€ 280$ per year. Hence, this implies a net welfare gain of roughly $€ 300$ per household as a result of parking policy.

Finally, as a side result, it appears that in areas without paid parking, in line with the discussion above, residents attach much less value to private parking than in case of paid onstreet parking, because residents will frequently be able to park on the street for free. In addition, it is important to note that, in case of paid-parking, residents seem to be indifferent to owning an outside parking spot, carport or a single garage, indicating that the value of the parking space is expressed exclusively through the added value for parking, in line with our assumption that in paid parking areas, residents use parking spaces exclusively for car parking.

\subsection{Sensitivity analyses}

The effect of parking tariffs (no, low tariff, high tariff) and waiting list is identified using a difference-in-difference methodology. A standard objection to such a strategy is that changes in parking tariffs are correlated to changes in house prices for reasons unknown to us. For example, during the period of observation, paid parking has been introduced mainly at the edge of the city, and it may be the case that house price increases at the edge of the city were less than in the centre for reasons unrelated to parking. To deal with this criticism, we have included four additional controls that interact the year of observation with the distance to the centre. The results are presented in column (2) of Table 2.

Furthermore, one may object that our specification of a large number of different types of parking spaces is too flexible, in particular when we focus on the additional effect of the waiting 
list, because the number of observations per variable is limited. As a consequence, standard errors are quite large, so interpretation of the point estimates may not be appropriate. We have therefore estimated a third specification (see column (3) of Table 2), where we restrict the coefficients of parking spaces of identical size to be equal to each other. Essentially, the results do not change.

We have re-estimated specification (3) distinguishing between short (less than one year) and long (more than one year) waiting lists. These results show that waiting lists shorter than one year have no effect on the price $(0.0002$, with standard error equal to 0.0189$)$, whereas the effect of longer waiting lists is negative (-0.015), but still insignificant (standard error 0.015). It appears now that the additional effect of short waiting lists on single parking places is positive but insignificant, whereas the additional effect of long waiting lists on single parking spaces is 0.056 (with a standard error of 0.018). So, it appears, as one would expect, that the additional effect of 0.46 of specification (3), is identified using long waiting lists.

\section{Conclusion}

In the growing economic literature on downtown parking, the importance of cruising, searching for a parking spot, has come to the fore (e.g., Arnott and Inci, 2006). This paper is the first to examine empirically the (private) cost of cruising. To be more precise, we focus on the cost of cruising for residents in Amsterdam, the Netherlands. In most large cities in the world, parking for residents is directly or indirectly subsidised, but policies largely differ in detail. In Amsterdam, in large parts of the city, on-street parking lots are not for free: parking tariffs are among the highest in the world. Despite these high parking tariffs, cruising for on-street parking 
spaces is still common in many areas of Amsterdam, because many residents have access to parking permits at a low price.

In the current paper, we have identified the residents' costs of cruising based on the difference in selling prices of residences with and without private parking places. Unobserved heterogeneity is taken care of by using a area-fixed-effect estimator. The average distance of houses within the same area is only 28 metre. We demonstrated that the costs of cruising capitalise into housing prices. These costs are estimated to be about $€ 1.30$ per day.

In areas with paid parking, households that live in that area, but only those that occupy residences without private parking, may obtain one on-street parking permit (which can be used in the neighbourhood of their residence). The tariff for the residents' parking permit is much less than the tariff for on-street parking space used by the residents who have to pay the same tariff for parking as non-residents. In certain areas of Amsterdam, residents have to queue for on-street parking permits with average waiting times of more than 3 years. We have demonstrated that the costs of waiting for parking permits are capitalised into housing prices, which allows us to derive the residents' willingness to pay for on-street parking permits (given the structure of on-street parking tariffs set by the municipality). We demonstrate that the average residents' willingness to pay for a parking permit is about $€ 8$ per day which far exceeds the parking permit's tariff, but far below the on-street tariff (which is applicable to residents without a permit). This suggests large efficiency losses of parking policy regarding the use of on-street parking lots. In particular, if the on-street parking tariff is a good indicator of the economic costs of parking, then this suggests that the welfare costs due to the common policy to offer parking permits to residents are substantial, in line with suggestions by theoretical economists (see, for example, Arnott and Inci, 
2006) as well as numerical simulation models (Calthrop et al., 2000; Proost and van Dender, 2008).

In Amsterdam, parking permits are essentially allocated for free which induces a waitinglist. An alternative way to allocate parking permits, and likely economically more efficient, would to introduce tradable parking permits. In this case, the municipality only has to decide the total number of permits that will be distributed among residents. Residents are then free to trade these permits (maybe only with other residents), so a market in parking permits is created, with corresponding market prices for permits. The main practical difficulty with trading systems is the initial amount of permits to be distributed. However, in case of on-street parking permits, the amount can be determined in a fairly objective way using information about the number of on street parking spaces and the desirable parking vacancy rate (Anderson and De Palma, 2004). 


\section{References}

Anderson, S.P., and A. De Palma (2004). The economics of pricing parking. Journal of Urban Economics, 55, 1-20.

Arnott, R., A. De Palma, and R. Lindsey (1991). A temporal and spatial equilibrium analysis of commuter parking. Journal of Public Economics, 45, 301-335.

Arnott, R. (2006). Spatial competition between parking garages and downtown parking policy. Transport Policy, 13, 458-469.

Arnott, R., and E. Inci (2006). An integrated model of downtown parking and traffic congestion. Journal of Urban Economics 60, 418 - 442.

Arnott, R., and J. Rowse (1999). Modelling parking. Journal of Urban Economics, 45, 97-124.

Borger, B., and B. Wuyts. (2007) Commuting, Transport Tax Reform and the Labour Market: Employerpaid Parking and the Relative Efficiency of Revenue Recycling Instruments. Urban Studies, 46(1), 213-233

Calthrop E., S. Proost, and K. van Dender (2000). Parking policies and road pricing. Urban Studies, 37(1), 63-76.

Calthrop, E. (2001). Essays in urban transport economics, PhD Thesis 151, Leuven.

Calthrop, E. (2002), Evaluating on-street parking policy, Working Paper 2002-03, Leuven.

Gautier, P.A., A. Siegmann and A. Van Vuuren (2009). Terrorism and attitudes towards minorities: The effect of the Theo van Gogh murder on house prices in Amsterdam. Journal of Urban Economics, 65(2009), 113-126.

Glazer, A., and E. Niskanen (1992). Parking fees and congestion. Regional Science and Urban Economics, 22, 123-132. 
Goodman, A.C., and T.G. Tibodeau (2003). Housing market segmentation and hedonic prediction accuracy. Journal of Housing Economics, 12(3), 181-201.

Moulton, B.R. (1990). An illustration of a pitfall in estimating the effects of aggregate variables on micro units. The Review of Economics and Statistics, 72(2), 334-338.

Proost, S., and K. van Dender (2008). Optimal urban transport pricing in the presence of congestion, economies of density and costly public funds. Transportation Research Part A, 42, 1220-1230.

Rosen, S. (1974). Prices and implicit markets: product differentiation in pure competition. Journal of Political Economy, 82(1), 34-55.

Shoup, D.C. (2004), The ideal source of local public revenue, Regional Science and Urban Economics, 34, 753-784.

Shoup, D.C. (2005). The High Cost of Free-parking. Planners Press, Chicago.

Shoup, D.C. (2006). Cruising for Parking. Transport Policy, 13, 479 - 486.

Small, K.A., C. Winston, and J. Yan (2005). Uncovering the distribution of motorists' preferences for travel time and reliability. Econometrica, 73, 4, 1367-1382.

Stevenson, S. (2004). New empirical evidence on heteroskedasticity in hedonic housing models. Journal of Housing Economics, 13(2), 136-153.

Verhoef, E., P. Nijkamp, and P. Rietveld (1995). The economics of regulatory parking policies: the (im)possibilities of parking policies in traffic regulation. Transportation Research Part A, 29, 141-156.

Vickrey, W.S. (1969). Congestion theory and transportation investment. American Economic Review, 59, 251-261.

WBO (2002). Dutch Housing Survey, the Hague 


\begin{tabular}{|c|c|c|c|c|c|}
\hline & Tariff $=0$ & $0<$ Tariff $\leq 2.2$ & $2.2<$ Tariff $\leq 3.5$ & Tariff $>3.5$ & Total \\
\hline Average transaction price & 181,281 & 256,387 & 284,106 & 365,482 & 251,159 \\
\hline Number of observations & 7,174 & 12,292 & 2,130 & 3,209 & 24,805 \\
\hline Residences in waiting-list areas (percent) & 0.00 & 17.18 & 16.62 & 100.00 & 22.90 \\
\hline Private parking (percent) & 13.81 & 7.95 & 7.37 & 8.53 & 9.67 \\
\hline Outside private parking (percent) & 6.48 & 1.92 & 1.78 & 2.34 & 3.28 \\
\hline Garage (percent) & 2.15 & 2.22 & 1.60 & 1.30 & 2.02 \\
\hline Carport (percent) & 4.54 & 3.33 & 3.57 & 4.00 & 3.78 \\
\hline Carport and garage (percent) & 0.18 & 0.20 & 0.14 & 0.22 & 0.19 \\
\hline Double garage (percent) & 0.46 & 0.27 & 0.28 & 0.01 & 0.38 \\
\hline
\end{tabular}


Table 2. Hedonic House Price Analysis

\begin{tabular}{|c|c|c|c|}
\hline & $(1)$ & $(2)$ & $(3)$ \\
\hline \multicolumn{4}{|l|}{ Parking area characteristics } \\
\hline On-street parking (low tariff) & $-0.037(0.010)$ & $-0.037(0.012)$ & $-0.042(0.009)$ \\
\hline On-street parking (high tariff) & $-0.049(0.022)$ & $-0.049(0.022)$ & $-0.050(0.027)$ \\
\hline Waiting-list for parking permit & $-0.013(0.016)$ & $-0.013(0.016)$ & $-0.012(0.015)$ \\
\hline \multicolumn{4}{|l|}{ In paid parking areas } \\
\hline Parking spot (outside) & $0.068(0.012)$ & $0.068(0.012)$ & $0.069(0.012)$ \\
\hline Carport & $0.060(0.010)$ & $0.060(0.010)$ & $0.059(0.010)$ \\
\hline Garage & $0.078(0.014)$ & $0.078(0.014)$ & $0.077(0.013)$ \\
\hline Carport and garage & $0.102(0.025)$ & $0.102(0.025)$ & $0.091(0.022)$ \\
\hline Double garage & $0.143(0.030)$ & $0.143(0.029)$ & $0.149(0.026)$ \\
\hline \multicolumn{4}{|l|}{ In paid parking areas with parking permit waiting-list } \\
\hline Parking spot (outside) & $0.057(0.029)$ & $0.057(0.029)$ & \\
\hline Carport & $0.038(0.019)$ & $0.038(0.019)$ & $0.046(0.017)$ \\
\hline Garage & $0.038(0.029)$ & $0.038(0.029)$ & \\
\hline Carport and garage & $0.040(0.039)$ & $0.040(0.039)$ & \\
\hline Double garage & $0.079(0.057)$ & $0.079(0.057)$ & $0.061(0.040)$ \\
\hline \multicolumn{4}{|l|}{ In areas without paid parking } \\
\hline Parking spot (outside) & $0.000(0.011)$ & $0.000(0.011)$ & $-0.001(0.010)$ \\
\hline Carport & $0.027(0.015)$ & $0.027(0.015)$ & $0.016(0.014)$ \\
\hline Garage & $0.024(0.015)$ & $0.023(0.015)$ & $0.024(0.015)$ \\
\hline Carport and garage & $0.090(0.030)$ & $0.090(0.030)$ & $0.073(0.037)$ \\
\hline Double garage & $0.099(0.069)$ & $0.099(0.069)$ & $0.091(0.065)$ \\
\hline \multicolumn{4}{|l|}{ Housing characteristics } \\
\hline $\log ($ inside square metres)) & $0.742(0.009)$ & $0.742(0.009)$ & $0.741(0.009)$ \\
\hline Number of rooms & $0.011(0.002)$ & $0.010(0.002)$ & $0.011(0.002)$ \\
\hline Central heating & $0.051(0.004)$ & $0.051(0.004)$ & $0.050(0.004)$ \\
\hline Garden & $0.031(0.005)$ & $0.031(0.005)$ & $0.033(0.005)$ \\
\hline Well maintained garden & $0.046(0.007)$ & $0.044(0.007)$ & $0.047(0.007)$ \\
\hline Building period (10 dummies) & yes & yes & yes \\
\hline Housing type controls (e.g., apartment, flat) & yes & yes & yes \\
\hline \multicolumn{4}{|l|}{ Locational characteristics } \\
\hline Distance to CBD (100 m) & $0.001(0.001)$ & $0.001(0.001)$ & $0.001(0.002)$ \\
\hline Nearest train station $<200 \mathrm{~m}$ & $0.052(0.046)$ & $0.053(0.042)$ & $0.053(0.042)$ \\
\hline $200 \mathrm{~m}<$ Nearest train station $<800 \mathrm{~m}$ & $0.024(0.017)$ & $0.020(0.016)$ & $0.020(0.016)$ \\
\hline Nearest highway ramp $<200 \mathrm{~m}$ & $0.015(0.044)$ & $0.020(0.043)$ & $0.020(0.043)$ \\
\hline $200 \mathrm{~m}<$ Nearest highway ramp $<800 \mathrm{~m}$ & $0.026(0.024)$ & $0.025(0.024)$ & $0.025(0.024)$ \\
\hline Interaction terms between year and distance to CBD & no & yes & yes \\
\hline Year controls & yes & yes & yes \\
\hline Area controls & yes & yes & yes \\
\hline Number of areas & 6,241 & 6,241 & 6,241 \\
\hline Number of observations & 24,804 & 24,804 & 24,804 \\
\hline
\end{tabular}

note: Robust standard errors allowing for area clustering are in parentheses 